\title{
Heavy Metals of Santiago Island (Cape Verde) Alluvial Deposits: Baseline Value Maps and Human Health Risk Assessment
}

\author{
Marina M. S. Cabral Pinto * and Eduardo A. Ferreira da Silva \\ Department of Geosciences, GeoBioTec Research Centre, University of Aveiro, 3810-193 Aveiro, Portugal; \\ eafsilva@ua.pt \\ * Correspondence: marinacp@ci.uc.pt; Tel.: +35-196-433-2189
}

Received: 16 November 2018; Accepted: 17 December 2018; Published: 20 December 2018

\begin{abstract}
The chemical composition of surface geological materials may cause metabolic changes and promote endemic diseases (e.g., oncological, gastrointestinal, neurological or cardiovascular diseases). The results of a geochemical survey is presented following the guidelines proposed by the International Project IGCP 259 performed on the alluvium of Santiago Island (Cape Verde) and focused on public health issues. Geochemical mapping is the base knowledge needed to determine critical contents of potential toxic elements and the potentially harmful regions in the planet. This work presents maps of baseline values of potentially toxic elements (As, $\mathrm{Cd}, \mathrm{Co}, \mathrm{Cr}, \mathrm{Cu}, \mathrm{Hg}, \mathrm{Mn}, \mathrm{Ni}$, $\mathrm{Pb}, \mathrm{V}$, and $\mathrm{Zn}$ ) in Santiago alluvium and the assessment of their human health risks. According to the results the $\mathrm{Cd}, \mathrm{Co}, \mathrm{Cr}, \mathrm{Ni}$ and $\mathrm{V}$ baseline values are above the Canadian guidelines for stream sediments (for any proposal use) and for soils (for agricultural and residential proposal uses) and also above the target values of Dutch guidelines. Hazard indexes (HI) were calculated for children and adults. For children (HI) are higher than 1 for $\mathrm{Co}, \mathrm{Cr}$ and $\mathrm{Mn}$, indicating potential non-carcinogenic risk. For the other elements and for adults there is no potential non-carcinogenic risk. Cancer risk was calculated for $\mathrm{Cd}, \mathrm{Cr}$ and $\mathrm{Ni}$ exposures, for adults and children, and the results are only slightly higher than the carcinogenic target risk of $1 \times 10^{-6}$ for adults exposed to $\mathrm{Cr}$ by inhalation. However, these results may be underestimated because alluvial contaminants may be indirectly ingested by groundwater and by crop and vegetables consumption.
\end{abstract}

Keywords: potentially harmful elements; alluvial deposits; baseline values (BV), human health risk assessment; Santiago Island; Cape Verde

\section{Introduction}

Geochemical surveys were developed in the last century [1-6] mainly as a means of geochemical prospecting of ore deposits [7,8]. Geochemical databases have been carried out in many regions [9-13], countries [7,14-18], multinational regions [19] and, more recently, continents [20-22], at various scales, ranging from high to very low density (e.g., $>1$ sample $/ \mathrm{km}^{2}$ to 1 sample $/ 10,000 \mathrm{~km}^{2}$, respectively). Geochemical surveys application has expanded to also encompass environmental monitoring, land-use decision support, natural resource management, and medical geology [7,23]. A diversity of sampling media have been targeted by geochemical surveys over time, which includes rock, sediment, soil, alluvium, ground water, surface water, dust, and vegetation [22]. In order to understand the transference, mobility, residence and biogeochemical processes of chemical elements few recent surveys have even targeted several media [24,25].

Geochemical surveys are especially important in developing countries like Cape Verde, where intervention limits for near-surface environment are not yet established. Considering this lack of 
information a high-density (aprox. $1 / 3 \mathrm{~km}^{2}$ ) geochemical survey in Santiago Island, Cape Verde archipelago, following the guidelines proposed by the International Geological Correlation Program (IGCP) Project 259 [1], was conducted in order to compile the first environmental geochemical atlas for that region. This paper presents the baseline value (BV) Santiago Island maps of some potentially toxic elements in alluvial deposits. Alluvial deposits are important natural resources, in particular in areas of limited rainfall when weathering profiles are very thin or non-existent, being the most adequate place for local agriculture. Knowledge of the geochemistry of near-surface environment is essential as it contributes to the improvement of the nutritional status of the population [26,27] and helps to understand the causes of some endemic diseases which can persist through out the life course due to heavy metal exposure, such as $\mathrm{As}, \mathrm{Cr}, \mathrm{Al}, \mathrm{Mn}, \mathrm{Pb}, \mathrm{Hg}, \mathrm{Cu}, \mathrm{Co}$, etc. Some elements can naturally accumulate on alluvial deposits in concentrations that are toxic to the plant, to the animal feeding on it and to humans. The dispersion of these elements in the environment is mainly carried out by water and air, which are vehicles linking the inorganic environment to life. The inhabitants of Santiago Island depend on groundwater for consumption and for agriculture and the flux water-vegetables-human also deserve evaluation, because endemic diseases can be controlled with proper measures, if its cause is well constrained. Some of these potentially toxic elements (PTEs) can lead to long-term carcinogenic and non-carcinogenic health risks and early environmental and occupational exposure to PTEs in different locales around the world has been related to oncological disease and mortality, neurological or cardiovascular diseases [28-40], etc. The widespread existence of PTEs has become one of the most serious environmental concerns around the globe and the development of efficient and selective chemical sensors to detect such potentially toxic elements have been a priority [41-48].

This study had the following objectives: (1) present a geochemistry survey of alluvial deposits for the studied metals and metalloid; (2) define the baseline values on Santiago Island; (3) evaluate the environmental risks; and (4) evaluate the human health risk, in areas naturally enriched with metals.

\section{Settings of the Archipelago of Cape Verde and Santiago Island}

The archipelago of Cape Verde (composed by 10 islands-Figure 1) is located at the eastern shore of the Atlantic Ocean, $500 \mathrm{~km}$ west from Senegal's Cape Verde, off the western shore of Africa (Figure 1). Santiago island $\left(991 \mathrm{~km}^{2}\right)$, located in the southern part of the archipelago, is the biggest island and with half of the country's population [7].
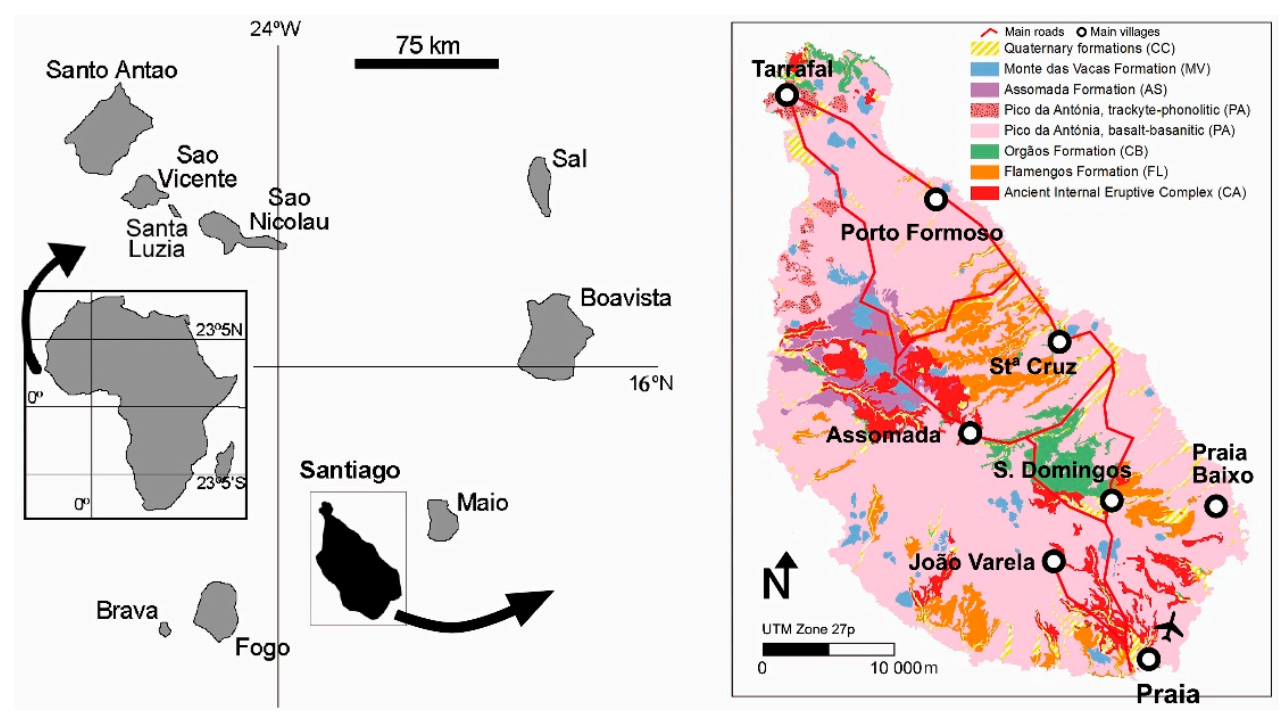

Figure 1. The Cape Verde Archipelago and its location on Senegal's western coast, adapted from [7] and geological cartography of the island of Santiago, Cape Verde, adapted from [49].

Santiago Island has a semi-arid climate, with strong winds during the dry season, and a mean annual precipitation of $321 \mathrm{~mm}$, mainly due to torrential rains, during the wet season [50]. It has 
$215 \mathrm{~km}^{2}$ of arable area and estimated hydric resources of $56.6 \times 106 \mathrm{~m}^{3} /$ year on the surface, and $42.4 \times 106 \mathrm{~m}^{3} /$ year underground [51].

The works carried out by $[49,52-55]$ allowed the establishment of the volcanostratigraphy of the island of Santiago (Figure 1). Table 1 provides a brief description of the geologic units in Santiago, named: Ancient Internal Eruptive Complex (CA), Flamengos Formation (FL), Orgãos Formation (CB), Eruptive Complex of Pico da Antónia (PA), Assomada Formation (AS), Monte das Vacas Formation (MV), and quaternary formations (CC).

Table 1. Geologic units, outcrop, rock type and composition, primary minerals of Santiago Island, Cape Verde.

\begin{tabular}{|c|c|c|c|c|}
\hline Geological Formation & Outcrop & Rock Type & Composition & Primary Minerals \\
\hline $\begin{array}{l}\text { CA-Ancient internal } \\
\text { eruptive complex }\end{array}$ & $\begin{array}{l}\text { Centre, centre- } W \\
\text { and in stream } \\
\text { valleys }\end{array}$ & $\begin{array}{l}\text { Subaerial and submarine lava } \\
\text { flows and pyroclastic deposits; } \\
\text { dykes and intrusive rocks }\end{array}$ & $\begin{array}{l}\text { Basalts-basanites, } \\
\text { phonolites-trachytes } \\
\text { and carbonatites }\end{array}$ & $\begin{array}{c}\text { Feldspar pyroxene } \\
\text { carbonates, olivine, } \\
\text { phyllosilicates }\end{array}$ \\
\hline $\begin{array}{l}\text { FL_Flamengos } \\
\text { formation }\end{array}$ & $\begin{array}{l}\text { NE-flank of the } \\
\text { island }\end{array}$ & $\begin{array}{l}\text { Submarine lava flows with } \\
\text { subordinated breccias and } \\
\text { tuffs }\end{array}$ & Basanites & $\begin{array}{l}\text { Pyroxene, Fe-Ti } \\
\text { oxides, olivine, } \\
\text { feldspar }\end{array}$ \\
\hline $\mathrm{CB}$-Orgãos formation & Centre-E & $\begin{array}{l}\text { Volcano-sedimentary deposits; } \\
\text { rare lava flowss }\end{array}$ & Diverse & $\begin{array}{c}\text { Pyroxene, } \mathrm{Fe}-\mathrm{Ti} \\
\text { oxides, carbonates, } \\
\text { feldspar }\end{array}$ \\
\hline $\begin{array}{l}\text { PA—Pico da Antónia } \\
\text { eruptive complex }\end{array}$ & $\begin{array}{l}\text { Widespread in the } \\
\text { island }\end{array}$ & $\begin{array}{l}\text { Subaerial and submarine lava } \\
\text { flows, dykes and pyroclastic } \\
\text { material; intercalated } \\
\text { sedimentary deposits }\end{array}$ & $\begin{array}{l}\text { Basalts-basanites, } \\
\text { phonolites-trachytes } \\
\text { and conglomerates }\end{array}$ & $\begin{array}{l}\text { Pyroxene, Fe-Ti } \\
\text { oxides, feldspar } \\
\quad \text { olivine }\end{array}$ \\
\hline $\begin{array}{l}\text { AS-Assomada } \\
\text { formation }\end{array}$ & Centre-W & $\begin{array}{l}\text { Subaerial lava flows and some } \\
\text { pyroclasts }\end{array}$ & Basanites & $\begin{array}{l}\text { Pyroxene, Fe-Ti } \\
\text { oxides, feldspar, } \\
\quad \text { olivine }\end{array}$ \\
\hline $\begin{array}{l}\text { MV_-Monte das Vacas } \\
\text { formation }\end{array}$ & $\begin{array}{l}50 \text { cinder cones } \\
\text { throughout the } \\
\text { island }\end{array}$ & $\begin{array}{l}\text { Subaerial pyroclasts and small } \\
\text { subordinated lava flows }\end{array}$ & Basanites & $\begin{array}{l}\text { Pyroxene, Fe-Ti } \\
\text { oxides, feldspar, } \\
\text { olivine }\end{array}$ \\
\hline $\begin{array}{l}\text { CC-recent } \\
\text { sedimentary } \\
\text { formations }\end{array}$ & $\begin{array}{l}\text { Mostly in stream } \\
\text { valleys }\end{array}$ & $\begin{array}{l}\text { Alluvial, aeolian and marine } \\
\text { deposits }\end{array}$ & Diverse & $\begin{array}{c}\text { Pyroxene, } \mathrm{Fe}-\mathrm{Ti} \\
\text { oxides, carbonates, } \\
\text { feldspar }\end{array}$ \\
\hline
\end{tabular}

\section{Materials and Methods}

\subsection{Sample Collection, Chemical Analysis}

Three hundred and forty near surface alluvium composite samples (0-15 cm depth) were sampled across the Santiago Island, at a density of approximately 0.3 site $/ \mathrm{km}^{2}$. On each site the composite sample $(\sim 1 \mathrm{~kg})$ was obtained by collecting five points, spaced approximately $50 \mathrm{~m}$. These samples represent pristine alluvial deposits developed from all the geological formations in Santiago Island. To establish the sampling sites and the treatment of the samples, the guidelines of the IGCP 259 project were followed [1]. Field duplicate samples were taken at every 10 sites and locations affected by pollution were avoided. Samples were then sieved to $<2 \mathrm{~mm}$, being this fraction used for all chemical analyses.

The chemical analysis was performed at ACME Analytical Laboratories, Ltd. (Vancouver, BC, Canada). Individual samples were digested in aqua regia and analysed by inductively coupled plasma-mass spectrometry (ICP-MS, ALS Global, Vancouver, Canada) for As, Cd, Co, Cr, Cu, Hg, $\mathrm{Mn}, \mathrm{Ni}, \mathrm{Pb}, \mathrm{V}$, and $\mathrm{Zn}$. Digestion with aqua regia is a chemical attack method used in heavy metal environmental studies because it is effective in removing the more mobile elements normally associated with clay minerals, organic matter and other secondary minerals [1].

\subsection{Analytical Quality Control, Statistical Analysis and Baseline Value}

The data resulting from the chemical analysis of the elements was subjected to several data quality tests in order to determine which elements have reliable data to be interpreted by subsequent statistical 
analysis and is well described in Cabral Pinto et al. [7]. The methodology followed in this work to determine the baseline value of each metal at each sampling site followed the guidelines of the IGCP 259 project [1]. The mapping of the BVs was performed by ordinary kriging using a theoretical model of spatial continuity fitted to the experimental variograms calculated for each metal (Supplementary Materials, Table S1). Cross validation was carried out for each interpolated variable to assess if the fitted model was suitable for the experimental variogram. The root-mean-square error (RMSE) was used to measure the differences between values predicted by the model and the actual values. The RMSE ranges from 0 to infinity, with 0 corresponding to the ideal. The baseline value representative of the entire Santiago Island (BV-S) was calculated as the median of the data set limited by the Tukey range [56].

\subsection{Risk Assessment}

The environmental risk (ER) is calculated for PTE using Canadian [57] and Dutch [58] legislations for soils and sediments. For each element ER = BV-S/P, where computed. BV-S is the baseline element concentration in Santiago Island and $\mathrm{P}$ is the permissive level of that element, according to the legislations.

The non-carcinogenic and carcinogenic risks for residents of the Santiago Island were estimated according the United States Environmental Protection Agency (USEPA) methodology [59]. The equations used to determine the exposition to toxic elements via ingestion, dermal contact and inhalation are:

$$
\begin{gathered}
\mathrm{CDI}_{\text {ingest }}=\frac{\mathrm{C} \times \mathrm{IRS} \times \mathrm{EF} \times \mathrm{ED}}{\mathrm{BW} \times \mathrm{AT}} \times \mathrm{CF} \\
\mathrm{CDI}_{\text {dermal }}=\frac{\mathrm{C} \times \mathrm{SA} \times \mathrm{AF} \times \mathrm{ABS} \times \mathrm{EF} \times \mathrm{ED}}{\mathrm{BW} \times \mathrm{AT}} \times \mathrm{CF} \\
\mathrm{CDI}_{\text {inhalation }}=\frac{\mathrm{C} \times \mathrm{ET} \times \mathrm{EF} \times \mathrm{ED}}{\mathrm{PEF} \times 24 \times \mathrm{AT}}
\end{gathered}
$$

where CDI = Chronic Daily Intake ( $\mu \mathrm{g} / \mathrm{kg}$ bw/day); $\mathrm{C}$-Concentration of chemical in alluvial deposits $\left(\mathrm{mg} \mathrm{kg}^{-1}\right)$; IRS-Ingestion Rate of Alluvium (mg day $\left.{ }^{-1}\right)$; EF-Exposure Frequency (350 days/year); ED-Exposure Duration (35 years for adult; 6 year for children); BW—Body Weight (70 kg for adult; $15 \mathrm{~kg}$ for children); AT—Averaging Time (365 days); CF-Conversing Factor $\left(10^{-6} \mathrm{~kg} \mathrm{mg}^{-1}\right)$; SA-Skin Surface Area available for contact $\left(2373 \mathrm{~cm}^{2}\right.$ for children and $\left.6032 \mathrm{~cm}^{2}\right)$; AF-Alluvium to skin Adherence Factor $\left(0.2 \mathrm{mg} \cdot \mathrm{cm}^{-2}\right.$ for children and $0.07 \mathrm{mg} \cdot \mathrm{cm}^{-2}$ for adult); ABS-Absorption Factor (0.001); ET-Exposure Time (12 h.day $\left.{ }^{-1}\right)$; PEF-Particle Emission Factor: $1.36 \times 109 \mathrm{~m}^{3} \cdot \mathrm{kg}^{-1}$ [60]. In the formulas $C$ is the concentration of PTE in alluvial deposits, which is the $95 \%$ upper confidence limit (UCL) in accordance with the USEPA [61].

The human health risk caused by PTEs exposure is expressed as hazard quotient $(\mathrm{HQ})=\mathrm{ADD} / \mathrm{RfD}$. The ADD is the average daily dose that a children or adult is exposed. RfD is the reference dose which is the daily dosage that enables the exposed individual to sustain this level. The $\mathrm{HI}$ is the chronic hazard index that is the sum of the hazard quotient for multiple exposure pathways. When HI values $>1$, there is a chance that non-carcinogenic risk may occur; otherwise, $\mathrm{HI}<\mathrm{I}$ the opposite applies. The carcinogenic risks were calculated for $\mathrm{Cd}, \mathrm{Cr}$ and $\mathrm{Ni}$ exposure of Santiago Island population, according to the Exposure Factors Handbook $[60,62]$ and using the Slope Factors according to [63]. USEPA acceptable risk values for cancer risk $1 \times 10^{-4}$ to $1 \times 10^{-6}$.

\section{Results and Discussion}

\subsection{Baseline Value Maps}

Descriptive statistics including the median, mean \pm standard deviation, coefficient of variation percent, and the ranges of the analyzed metals concentrations along with the BV-S of Santiago Island 
were calculated and listed in Table 2. Figure 2 displays the spatial distribution of geochemical baseline values of the studied PTE at the sampling locations and also at all points of the interpolated spatial field.

Table 2. Statistical As, $\mathrm{Cd}, \mathrm{Co}, \mathrm{Cr}, \mathrm{Cu}, \mathrm{Hg}, \mathrm{Mn}, \mathrm{Ni}, \mathrm{Pb}, \mathrm{V}$ and $\mathrm{Zn}$ variables analysed, interval ranges, and the baseline values (BV-S) of metals from the alluvial deposits of Santiago Island $(n=340)$. Values expressed in $\mathrm{mg} \mathrm{kg}^{-1}$.

\begin{tabular}{ccccccccc}
\hline Variable & Median & Mean & SD & CV & Range & $\mathbf{P}_{\mathbf{5}}-\mathbf{P}_{\mathbf{9 5}}$ & Tukey Range & BV-S \\
\hline $\mathrm{As}$ & 0.3 & 0.6 & 0.6 & 1.07 & $0.3-7.2$ & $0.3-1.6$ & $0.3-1.4$ & 0.25 \\
$\mathrm{Cd}$ & 0.10 & 0.14 & 0.09 & 0.64 & $0.05-1.00$ & $0.05-0.30$ & $0.05-0.35$ & 0.10 \\
$\mathrm{Co}$ & 44.7 & 45.1 & 13.9 & 0.31 & $3.1-140$ & $26.4-66.1$ & $15.8-73.4$ & 44.65 \\
$\mathrm{Cr}$ & 114.0 & 124 & 68 & 0.55 & $8.0-463$ & $20.0-251.5$ & $8.0-264.0$ & 114 \\
$\mathrm{Cu}$ & 48.8 & 48.6 & 18 & 0.37 & $3.2-142$ & $17.6-77.8$ & $9.4-87.6$ & 48.7 \\
$\mathrm{Hg}$ & 0.01 & 0.01 & 0.01 & 0.74 & $0.01-0.08$ & $0.01-0.03$ & $0.01-0.04$ & 0.01 \\
$\mathrm{Mn}$ & 1191 & 1260 & 442 & 0.35 & $197-4210$ & $737-1976$ & $255-2162$ & 1182 \\
$\mathrm{Ni}$ & 155 & 161 & 76 & 0.47 & $6.8-477$ & $21.3-286$ & $6.8-338$ & 154 \\
$\mathrm{~Pb}$ & 3.9 & 5.2 & 6.6 & 1.26 & $1.4-81.4$ & $2.0-10.1$ & $1.4-10.1$ & 3.80 \\
$\mathrm{~V}$ & 160 & 161 & 45.7 & 0.28 & $24.0-372$ & $92.4-236$ & $50.5-263$ & 159 \\
$\mathrm{Zn}$ & 81.0 & 82.7 & 19.1 & 0.23 & $15.0-199$ & $57.0-189$ & $34.0-130$ & 81 \\
\hline
\end{tabular}

Med: median; SD: standard deviation; CV: variation coefficient; $\mathrm{P}_{5}-\mathrm{P}_{95}$ : the interval limited by the 5th and 95th percentile values; Tukey range (92) or non-anomalous range: $\mathrm{P}_{25}-1.5 \times\left(\mathrm{P}_{75}-\mathrm{P}_{25}\right)-\mathrm{P}_{75}+1.5 \times\left(\mathrm{P}_{75}-\mathrm{P}_{25}\right)$; BV-S (baseline value for Santiago): the median of the data limited by the Tukey range.

The mineralogical composition of alluvial deposits is primarily governed by the mineralogy of the bedrock, climatic conditions (precipitation, temperature, wind direction), and topography. Chemical weathering is not intense in Santiago, due to the semiarid climatic conditions and the vigorous relief. The alluvium mineralogy is a combination of components inherited from the original lithology, minerals resulting from the alteration of these primary components, and probably also wind-transported minerals, mainly from the Sahara Desert. The alluvial deposits on the island of Santiago are dominated by primary silicate minerals such as pyroxene, feldspar and olivine (Table 1). The main secondary minerals are phyllosilicates (smectite, palygorskite, kaolinite, mica/illite), calcite, hematite and also quartz. Other minerals occur, such as leucite, analcite, apatite, nepheline, magnetite, titanomagnetite, ilmenite, chromite, garnet, serpentine, zeolites, siderite, opal, barite, titanite, zircon, halite, aragonite, dolomite, brucite, and chlorite [23]. A brief description of soils types of Santiago Island is present in the Supplementary Materials (Table S2).

Figure 2 and Tables 1 and 3 shows that the alluvial deposits of Santiago Island, Cabo Verde, have a geochemical composition controlled by the type of underlying rock [23,64]. Most of the elements in the alluvium have a mainly geogenic origin.

Table 3. Baseline values of PTE from the alluvial deposits of Santiago, and admissible levels (in mg $\mathrm{kg}^{-1}$ ) in soils and stream sediments according to the Ontario (88) and Dutch guidelines (89).

\begin{tabular}{|c|c|c|c|c|c|}
\hline \multirow[b]{2}{*}{ Element } & \multirow[b]{2}{*}{ BV-S } & \multicolumn{3}{|c|}{ Canadian Guidelines } & \multirow{2}{*}{$\begin{array}{c}\text { Dutch Guidelines } \\
\text { Target Values }\end{array}$} \\
\hline & & $\begin{array}{l}\text { Soil Agricultural } \\
\text { Property Uses }\end{array}$ & $\begin{array}{l}\text { Soil Residential } \\
\text { Property Uses }\end{array}$ & $\begin{array}{l}\text { Sediments (All Types } \\
\text { of Property Uses }\end{array}$ & \\
\hline As & 0.25 & 11 & 18 & 6 & 29 \\
\hline $\mathrm{Cd}$ & 0.1 & 1 & 1.2 & 0.6 & 0.8 \\
\hline Co & 44.7 & 19 & 21 & 50 & 9 \\
\hline $\mathrm{Cr}$ & 114 & 67 & 70 & 26 & 100 \\
\hline $\mathrm{Cu}$ & 48.7 & 62 & 92 & 16 & 36 \\
\hline $\mathrm{Hg}$ & 0.01 & 0.3 & 0.2 & 0.2 & 0.3 \\
\hline $\mathrm{Mn}$ & 1182 & - & - & - & - \\
\hline $\mathrm{Ni}$ & 154 & 37 & 82 & 16 & 36 \\
\hline $\mathrm{Pb}$ & 3.8 & 45 & 129 & 31 & 85 \\
\hline V & 159 & 86 & 86 & 90 & - \\
\hline $\mathrm{Zn}$ & 81 & 290 & 290 & 120 & 140 \\
\hline
\end{tabular}

Note: The bold values highlight the concentrations of PTE of guidelines which are below the respectively concentrations of baseline values in Santiago alluvium. 


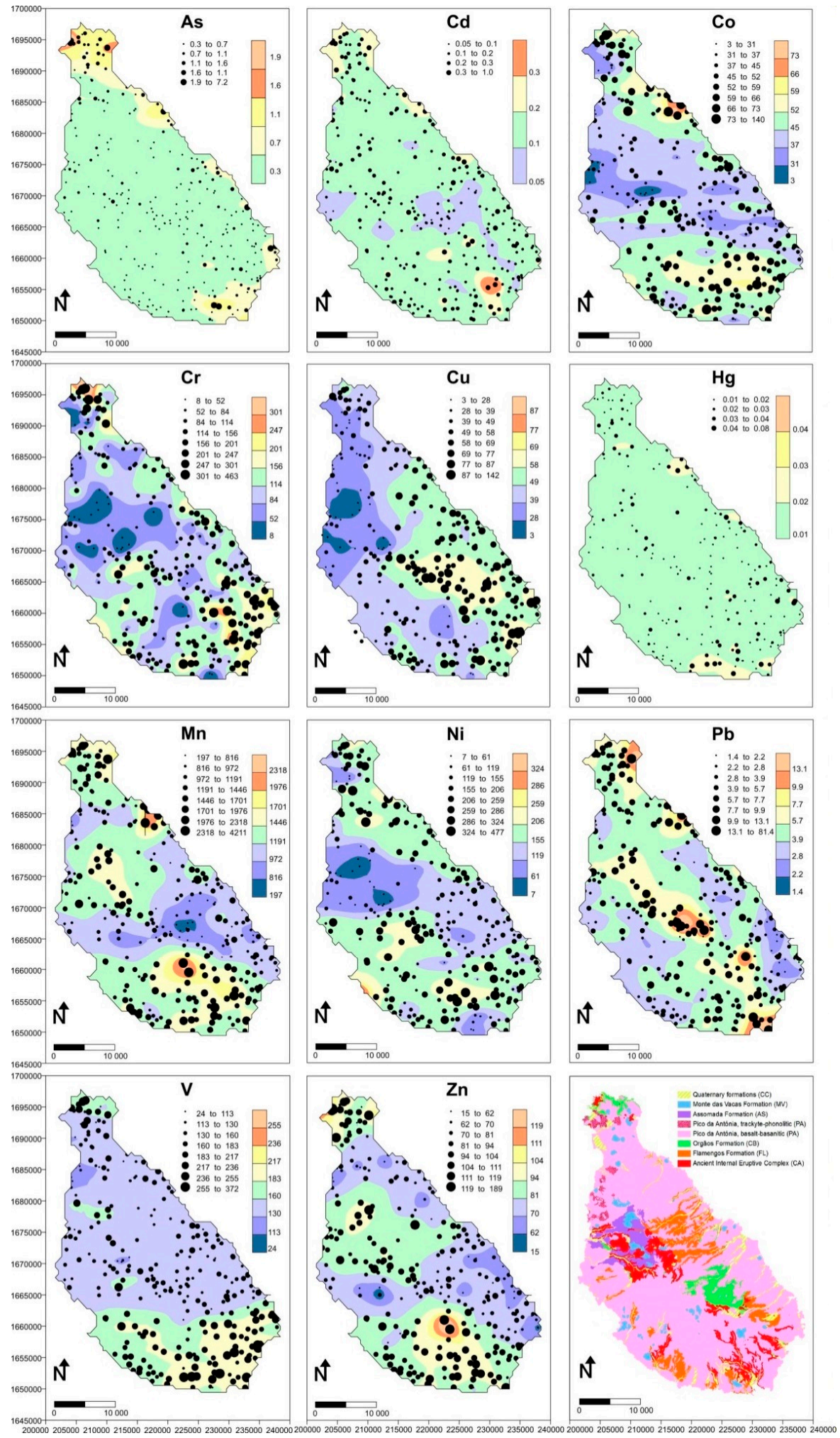

Figure 2. Spatial distribution of the $\mathrm{As}, \mathrm{Cd}, \mathrm{Co}, \mathrm{Cr}, \mathrm{Cu}, \mathrm{Hg}, \mathrm{Mn}, \mathrm{Ni}, \mathrm{Pb}, \mathrm{V}$ and $\mathrm{Zn}$ baseline values. Coordinate system: UTM zone 27p. The geological map of Figure 1 is shown in the last panel for easier comparison with the BV spatial fields.

\subsection{Risk Assessment}

The comparison of the BV-S of each studied PTE in the alluvial deposits of Santiago Island and the international values legislated as dangerous for certain uses (guideline values), is given in Table 3 . 
The BV-S of $\mathrm{Co}, \mathrm{Cr}, \mathrm{Cu}, \mathrm{Ni}$ and $\mathrm{V}$ are above the Canadian guidelines [57] for soils (for agricultural and residential uses), stream sediments (for any use) and above the target values of Dutch guidelines [58]. Manganese has not international guidelines for any property use, but its baseline value in Santiago alluvium is enriched relatively to upper crust values $\left(774 \mathrm{mg} \mathrm{kg}^{-1}\right.$ ) of Rudnick and Gao [65].

The Hazard Quotients (HQ) for ingestion, dermal contact and inhalation routes and Hazard Indexes (HI) were calculated (Table 4), for the PTE which are above the international guidelines for diverse property uses and also for Mn. Environmental exposure to Mn can induce parkinsonism and although the long-term medical significance of this finding is unclear, the data are troubling and point to the need for further investigation of manganese's health risks [66]. The selected elements are potentially toxic elements and some ( $\mathrm{Cd}, \mathrm{Cr}$ and $\mathrm{Ni}$ ) are also carcinogenic [67]. The pathways chosen were ingestion, inhalation and dermal contact and the calculations were performed for children and adults.

Table 4. HQ values for various pathways and elements and HI for elements from Santiago Island.

\begin{tabular}{ccccccccc}
\hline \multirow{2}{*}{ Element } & \multicolumn{2}{c}{ HQ Ingestion } & \multicolumn{2}{c}{ HQ Dermal } & \multicolumn{2}{c}{ HQ Inhalation } & HI \\
\cline { 2 - 8 } & Children & Adult & Children & Adult & Children & Adult & Children & Adult \\
\hline $\mathrm{Co}$ & $2.9 \times 10^{0}$ & $3.1 \times 10^{-1}$ & $8.2 \times 10^{-3}$ & $1.2 \times 10^{-3}$ & $4.1 \times 10^{-3}$ & $2.3 \times 10^{-3}$ & $\mathbf{2 . 9}$ & 0.3 \\
$\mathrm{Cr}$ & $1.1 \times 10^{0}$ & $1.2 \times 10^{-1}$ & $3.1 \times 10^{-3}$ & $4.7 \times 10^{-4}$ & $9.2 \times 10^{-4}$ & $5.2 \times 10^{-4}$ & $\mathbf{1 . 1}$ & 0.1 \\
$\mathrm{~V}$ & $1.9 \times 10^{-1}$ & $2.0 \times 10^{-2}$ & $5.3 \times 10^{-4}$ & $8.1 \times 10^{-5}$ & $1.2 \times 10^{-3}$ & $6.7 \times 10^{-4}$ & 0.2 & 0.0 \\
$\mathrm{Ni}$ & $2.6 \times 10^{-2}$ & $2.7 \times 10^{-3}$ & $7.2 \times 10^{-5}$ & $1.1 \times 10^{-5}$ & $7.2 \times 10^{-7}$ & $4.0 \times 10^{-7}$ & 0.0 & 0.0 \\
$\mathrm{Cu}$ & $6.2 \times 10^{-1}$ & $6.7 \times 10^{-2}$ & $1.7 \times 10^{-3}$ & $2.7 \times 10^{-4}$ & $8.8 \times 10^{-4}$ & $5.0 \times 10^{-4}$ & 0.6 & 0.1 \\
$\mathrm{Zn}$ & $8.4 \times 10^{-3}$ & $9.0 \times 10^{-4}$ & $2.3 \times 10^{-5}$ & $3.6 \times 10^{-6}$ & $2.3 \times 10^{-7}$ & $1.3 \times 10^{-7}$ & 0.0 & 0.0 \\
$\mathrm{Cd}$ & $4.0 \times 10^{-3}$ & $4.3 \times 10^{-4}$ & $4.5 \times 10^{-4}$ & $6.8 \times 10^{-5}$ & $1.1 \times 10^{-5}$ & $6.3 \times 10^{-6}$ & 0.0 & 0.0 \\
$\mathrm{Mn}$ & $1.1 \times 10^{0}$ & $1.2 \times 10^{-1}$ & $3.1 \times 10^{-3}$ & $4.7 \times 10^{-4}$ & $1.5 \times 10^{-2}$ & $8.3 \times 10^{-3}$ & $\mathbf{1 . 1}$ & 0.1 \\
\hline
\end{tabular}

Note: Bold values show the PTE values above 1 , and so highlight the elements which have potential non-carcinogenic risk.

The non-carcinogenic hazard indexes (HI) for all nine elements are presented in Table 4. For adults the $\mathrm{HI}$ are always smaller than 1 , whereas for children they are higher than 1 for $\mathrm{Co}(\mathrm{HI}=2.9), \mathrm{Cr}$ $(\mathrm{HI}=1.1)$, and $\mathrm{Mn}(\mathrm{HI}=1.1)$, indicating potential non-carcinogenic risk. The $\mathrm{HI}$ value of these elements is mainly controlled by the HQ ingestion, which are also higher than 1 for these 3 elements (Table 4 and Supplementary Figure S1). For the other elements and for adults there is no potential non-carcinogenic risk. The $\mathrm{HI}$ is $\mathrm{Co}>\mathrm{Cr}>\mathrm{Mn}$, for both children and adults. Compared to adult, children health index is higher, and their cumulative effect is also of concern for children. The high concentrations of PTE on near-surface environment can threaten human health via ingestion by geophagism, rare in adults, but quite common in children or by hand-to-mouth intake [68,69], and by inhalation of dust particles and by dermal contact, specially by farmers and construction workers. Potentially toxic elements can also threaten human health indirectly also by ingestion of contaminated groundwater. The studies of Türkdoğan et al. [70] show that high contents of these metals in volcanic soils, vegetables and fruits are related with endemic upper gastrointestinal disease region of Turkey.

The evaluation of cancer risk was performed for heavy metals which are potentially carcinogenic [66]. The results for cancer risk are higher than the carcinogenic target risk of $1 \times 10^{-6}$ [60] only for $\mathrm{Cr}$, for adults (Table 5). However, these results may be miscalculating the risk because the other pathways were not considered and contaminants may be indirectly ingested by groundwater and by crop and vegetables consumption. Pallegriti et al. [71] found that residents of Catania province with its volcanic region appear to have a higher incidence of papillary thyroid cancer than elsewhere in Sicily. Hawaii and the Philippines have revealed an increased incidence of thyroid cancer in volcanic areas [72]. The common denominator of these regions is their numerous volcanoes and the fact that several constituents of volcanic lava have been postulated as being involved in the pathogenesis of thyroid cancer. High incidences of thyroid cancer were found in volcanic areas (Hawaii and Iceland) and Malandrino et al. [73] found conclude that a volcanic environment may play a role in the pathogenesis of thyroid cancer. The areas of high incidence of endemic Kaposi sarcoma are characterised by a common geologic substrate, composed of fertile reddish-brown volcanic clay 
soils [74]. Chronic exposure to $\mathrm{Cr}$ has long been recognized as being capable to increase thyroid, sarcoma, lung, and, head cancer incidence among exposed human populations [75-79].

Table 5. Cancer risk values for $\mathrm{Cr}, \mathrm{Ni}$ and $\mathrm{Cd}$ from Santiago Island.

\begin{tabular}{ccc}
\hline \multirow{2}{*}{ Element } & \multicolumn{2}{c}{ Cancer risk } \\
\cline { 2 - 3 } & Children & Adult \\
\hline $\mathrm{Cr}$ & $3.2 \times 10^{-7}$ & $\mathbf{1 . 1} \times \mathbf{1 0}^{-\mathbf{6}}$ \\
$\mathrm{Ni}$ & $7.7 \times 10^{-9}$ & $2.5 \times 10^{-8}$ \\
$\mathrm{Cd}$ & $5.8 \times 10^{-11}$ & $1.9 \times 10^{-10}$ \\
\hline
\end{tabular}

Note: Bold values show the PTE values above 1 , and so highlight the elements which have potential non-carcinogenic risk.

\section{Conclusions}

Baseline maps show that the alluvial deposits of Santiago Island, Cabo Verde, have a geochemical composition controlled by the type of underlying rock, as most of the elements in the alluvium have mainly a geogenic origin. The environmental risk calculations shown that the Santiago Island alluvial deposits are naturally contaminated in $\mathrm{Co}, \mathrm{Cr}, \mathrm{Cu}, \mathrm{Ni}$ and $\mathrm{V}$, because these elements have contents well above those allowed by Canadian and Dutch legislations for soils, for agricultural and residential property uses (intervention limits for soils are not yet established in Cape Verde). The non-carcinogenic hazard indexes $(\mathrm{HI})$ were calculated for eight potentially toxic elements and they are always smaller than 1 for adults, considering that the alluvium contaminants enter the human body by soil ingestion, dermal contact and inhalation of dust particles. Most significant, non-carcinogenic Co hazard is 2.9 for children. Ingestion mainly controls the HI values, and ingestion by geophagism and by hand-to-mouth intake is much more common in children. The cancer risk is always lower or very close to the carcinogenic target value. Exposure to other pollutants through other media, such as the vegetables and water ingestion may constitute another sink of risk, that should be study in the future. The inhabitants of Santiago Island depend on groundwater for consumption and for agriculture and the flux water-vegetables-human also deserve evaluation, because endemic diseases can be controlled with proper measures, if its cause is well constrained.

Supplementary Materials: Supplementary Materials: The following are available online at http:/ /www.mdpi. com/1660-4601/16/1/2/s1, Figure S1: Hazard index (HI) and hazard quotient (HQ) for potentially toxic elements from Santiago Island. Symbols: HI-crosses; HQ for ingestion-balls; HQ for dermal contact-squares; HQ for inhalation-lines., Table S1: Parameters of the theoretical models of spatial continuity fitted to the experimental variogram of $\mathrm{As}, \mathrm{Cd}, \mathrm{Co}, \mathrm{Cu}, \mathrm{Cr}, \mathrm{Hg}, \mathrm{Mn}, \mathrm{Ni}, \mathrm{Pb}, \mathrm{V}$ and $\mathrm{Zn}$.

Author Contributions: Conceptualization, M.M.S.C.P. and E.A.F.d.S.; Methodology, M.M.S.C.P.; Software, M.M.S.C.P.; Validation, M.M.S.C.P. and E.A.F.d.S.; Formal Analysis, M.M.S.C.P.; Investigation, M.M.S.C.P.; Resources, M.M.S.C.P.; Data Curation, M.M.S.C.P.; Writing-Original Draft Preparation, M.M.S.C.P.; Writing-Review \& Editing, M.M.S.C.P. and E.A.F.d.S.; Visualization, M.M.S.C.P.; Supervision, E.A.F.d.S.; Project Administration, M.M.S.C.P.; Funding Acquisition, M.M.S.C.P.

Funding: The authors would like to thank the funding provided by the Portuguese Foundation for Science and Technology through the Research Development Grant of Marina Cabral Pinto (SFRH/BPD/71030/2010), Geobiotec Center, University of Aveiro (UID/GEO/04035/2013).

Acknowledgments: António Oliveira Cruz, Wlodziemierz Szymania, Jorge Brito and Luís Filipe Tavares are acknowledged for the logistic support provided in Santiago Island by the Jean Piaget University of Cape Verde. The authors also appreciate the support given by the National Institute of Agricultural Research and Development of Cape Verde. MCP acknowledges with great affection the field support provided by Ricardo Ramos during the field work.

Conflicts of Interest: The authors declare no conflicts of interest.

\section{References}

1. Darnley, A.G.; Björklund, A.; Bølviken, B.; Gustavsson, N.; Koval, P.V.; Plant, J.A.; Steenfelt, A.; Tauchid, M.; Xie, X. A Global Geochemical Database For Environmental and Resource Management. Recommendations for International Geochemical Mapping; Final Report of IGCP Project 259; UNESCO Publishing: Paris, France, 1995. 
2. Plant, J.A.; Smith, D.; Smith, B.; Williams, L. Environmental geochemistry at the global scale. Appl. Geochem. 2001, 16, 1291-1308. [CrossRef]

3. Araújo, P.R.M.; Biondi, C.M.; da Silva, F.B.V.; Nascimento, C.W.A.; Souza-Júnior, V.S. Geochemical soil anomalies: Assessment of risk to human health and implications for environmental monitoring. J. Geochem. Explor. 2018, 190, 325-335. [CrossRef]

4. Garret, R.G.; Reimann, C.; Smith, D.B.; Xie, X. From geochemical prospecting to international geochemical mapping: A historical overview. Geochem. Explor. Environ. Anal. 2008, 8, 205-217. [CrossRef]

5. Albanese, S.; De Vivo, B.; Lima, A.; Cicchella, D. Geochemical background and baseline values of toxic elements in stream sediments of Campania region (Italy). J. Geochem. Explor. 2007, 93, 21-34. [CrossRef]

6. Smith, D.B.; Reimann, C. Low-density geochemical mapping and the robustness of geochemical patterns. Geochem. Explor. Environ. Anal. 2008, 8, 219-227. [CrossRef]

7. Cabral Pinto, M.M.S.; Ferreira da Silva, E.A.; Silva, M.M.V.G.; Melo-Gonçalves, P. Heavy metals of Santiago Island (Cape Verde) top soils: Estimated background value maps and environmental risk assessment. J. Afr. Earth Sci. 2015, 101, 162-176. [CrossRef]

8. Cabral Pinto, M.M.S.; Dinis, P.A.; Silva, M.M.; da Silva, E.A.F. Sediment generation on a volcanic island with arid tropical climate: A perspective based on geochemical maps of topsoils and stream sediments from Santiago Island, Cape Verde. Appl. Geochem. 2016, 75, 114-124. [CrossRef]

9. Webb, J.S.; Thornton, I.; Thompson, M.; Howarth, R.J.; Lowenstein, P.L. The Wolfson Geochemical Atlas of England and Wales; Clarendon Press: Oxford, UK, 1978.

10. Bini, C.; Sartori, G.; Wahsha, M.; Fontana, S. Background levels of trace elements and soil geochemistry at regional level in NE Italy. J. Geochem. Explor. 2011, 109, 125-133. [CrossRef]

11. Redon, P.O.; Bur, T.; Guiresse, M.; Probst, J.L.; Toiser, A.; Revel, J.C.; Jolivet, C.; Probst, A. Modelling trace metal background to evaluate anthropogenic contamination in arable soils of south-western France. Geoderma 2013, 206, 112-122. [CrossRef]

12. Silva, Y.J.A.B.; Nascimento, C.W.A.; Cantalice, J.R.B.; Silva, Y.J.A.B.; Cruz, C.M.C.A. Watershed-scale assessment of background concentrations and guidance values for heavy metals in soils from a semiarid and coastal zone of Brazil. Environ. Monit. Assess. 2015, 187, 558-568. [CrossRef]

13. Inácio, M.; Pereira, V.; Pinto, M. The soil geochemical Atlas of Portugal: Overview and applications. J. Geochem. Explor. 2008, 98, 22-33. [CrossRef]

14. Rékási, M.; Filep, T. Fractions and background concentrations of potentially toxic elements in Hungarian surface soils. Environ. Monit. Assess. 2012, 184, 7461-7471. [CrossRef] [PubMed]

15. Cohen, D.R.; Rutherford, N.F.; Morisseau, E.; Zissimos, A.M. Geochemical patterns in the soils of Cyprus. Sci. Total Environ. 2012, 420, 250-262. [CrossRef] [PubMed]

16. Cappuyns, V.; Mallaerts, T. Background values of cobalt in Flemish and European soils. Geol. Belg. 2014, 17, 107-114.

17. Alfaro, M.R.; Montero, A.; Ugarte, O.M.; Nascimento, C.W.A.; Accioly, A.M.A.; Biondi, C.M.; Silva, Y.J.A.B. Background concentrations and reference values for heavy metals in soils of Cuba. Environ. Monit. Assess. 2015. [CrossRef] [PubMed]

18. Reimann, C.; Siewers, U.; Tarvainen, T.; Bityukova, L.; Eriksson, J.; Gilucis, A.; Gregorauskiene, V.; Lukashev, V.; Matinian, N.; Pasieczna, A. Baltic soil survey: Total concentrations of major and selected trace elements in arable soils from 10 countries around the Baltic Sea. Sci. Total Environ. 2000, 257, 155-170. [CrossRef]

19. Smith, D.B.; Cannon, W.F.; Woodruff, L.G.; Moreira Rivera, F.; Rencz, A.N.; Garrett, R.G. History and progress of the North American Soil Geochemical Landscapes Project, 2001-2010. Earth Sci. Front. 2012, 19, $19-32$.

20. Lado, L.R.; Hengl, T.; Reuter, H.I. Heavy metals in European soils: A geostatistical analysis of the FOREGS Geochemical database. Geoderma 2008, 148, 189-199. [CrossRef]

21. Caritat, P.; Cooper, M. A continental-scale geochemical atlas for resource exploration and environmental management: The National Geochemical Survey of Australia. Geochem. Explor. Environ. Anal. 2016, 16, 3-13. [CrossRef]

22. Thornton, I. Environmental geochemistry: 40 years research at Imperial College, London, UK. Appl. Geochem. 2012, 27, 939-953. [CrossRef] 
23. Cabral Pinto, M.M.S.; Silva, M.M.; da Silva, E.A.F.; Dinis, P.A.; Rocha, F. Transfer processes of potentially toxic elements (PTE) from rocks to soils and the origin of PTE in soils: A case study on the island of Santiago (Cape Verde). J. Geochem. Explor. 2017, 183, 140-151. [CrossRef]

24. Cabral Pinto, M.M.S.; Marinho-Reis, A.P.; Almeida, A.; Ordens, C.M.; Silva, M.M.; Freitas, S.; Ferreira da Silva, E.A.F. Human predisposition to cognitive impairment and its relation with environmental exposure to potentially toxic elements. Environ. Geochem. Health 2017, 1-18. [CrossRef] [PubMed]

25. Reuben, A.; Caspi, A.; Belsky, D.W.; Broadbent, J.; Harrington, H.; Sugden, K.; Houts, R.M.; Ramrakha, S.; Poulton, R.; Moffitt, T.E. Association of childhood blood lead levels with cognitive function and socioeconomic status at age 38 years and with IQ change and socioeconomic mobility between childhood and adulthood. JAMA 2017, 317, 1244-1251. [CrossRef] [PubMed]

26. Yao, Y.; Pei, F.; Kang, P. Selenium, iodine, and the relation with Kashin-Beck disease. Nutrition 2011, 27, 1095-1100. [CrossRef]

27. Selinus, O.; Alloway, B.J. Essentials of Medical Geology; Centeno, J.A., Finkelman, R.B., Fuge, R., Lindh, U., Smedley, P., Eds.; Springer: New York, NY, USA, 2013; p. 820.

28. Cabral Pinto, M.M.S.; Marinho-Reis, A.P.; Almeida, A.; Freitas, S.; Simões, M.R.; Diniz, M.L.; Moreira, P.I.; da Silva, F. Fingernail Trace Element Content in Environmentally Exposed Individuals and Its Influence on Their Cognitive Status in Ageing. Expor. Health 2018, 1-14. [CrossRef]

29. Obeng-Gyasi, E. Lead Exposure and Oxidative Stress-A Life Course Approach in US Adults. Toxics 2018, 6, 42. [CrossRef]

30. Phan, K.; Sthiannopkao, S.; Kim, K.W.; Wong, M.H.; Sao, V.; Hashim, J.H.; Aljunid, S.M. Health risk assessment of inorganic arsenic intake of Cambodia residents through groundwater drinking pathway. Water Res. 2010, 44, 5777-5788. [CrossRef]

31. Wongsasuluk, P.; Chotpantarat, S.; Siriwong, W.; Robson, M. Heavy metal contamination and human health risk assessment in drinking water from shallow groundwater wells in an agricultural area in Ubon Ratchathani province, Thailand. Environ. Geochem. Health 2014, 36, 169-182. [CrossRef]

32. Kavcar, P.; Sofuoglu, A.; Sofuoglu, S.C. A health risk assessment for exposure to trace metals via drinking water ingestion pathway. Int. J. Hyg. Environ. Health 2009, 212, 216-227. [CrossRef]

33. Nieuwenhuijsen, M.J. (Ed.) Exposure Assessment in Environmental Epidemiology; Oxford University Press: Evans Road Cary, NC, USA, 2015.

34. Kozlowski, H.; JanickaKlosb, A.; Brasunb, J.; Gaggelli, E.; Valensinc, D.; Valensinc, J. Copper, iron, and zinc ions homeostasis and their role in neurodegenerative disorders (metal uptake, transport, distribution and regulation). Coord. Chem. Rev. 2009, 253, 2665-2685. [CrossRef]

35. Needleman, H.L.; Schell, A.; Bellinger, D.; Leviton, A.; Allred, E.N. The long-term effects of exposure to low doses of lead in childhood: An 11-year follow-up report. N. Engl. J. Med. 1990, 322, 83-88. [CrossRef] [PubMed]

36. Liu, Q.R.; Walther, D.; Drgon, T.; Polesskaya, O.; Lesnick, T.G.; Strain, K.J.; de Andrade, M.; Bower, J.H.; Maraganore, D.M.; Uhl, G.R. Human brain derived neurotrophic factor (BDNF) genes, splicing patterns, and assessments of associations with substance abuse and Parkinson's Disease. Am. J. Med. Genet. Part B Neuropsychiatr. Genet. 2005, 134, 93-103. [CrossRef] [PubMed]

37. Gorell, J.M.; Johnson, C.C.; Rybicki, B.A.; Peterson, E.L.; Kortsha, G.X.; Kortsha, G.G.; Richardson, R.J. Occupational exposure to manganese, copper, lead, iron, mercury and zinc and the risk of Parkinson's disease. Neurotoxicology 1999, 20, 239-248. [PubMed]

38. Heindel, J.J.; Newbold, R.R.; Bucher, J.R.; Camacho, L.; Delclos, K.B.; Lewis, S.M.; Vanlandingham, M.; Churchwell, M.I.; Twaddle, N.C.; McLellen, M.; et al. NIEHS/FDA CLARITY-BPA research program update. Reprod. Toxicol. 2015, 58, 33-44. [CrossRef]

39. Tartaglione, A.M.; Venerosi, A.; Calamandrei, G. Early-life toxic insults and onset of sporadic neurodegenerative diseases-An overview of experimental studies. Available online: https:/ / link.springer. com/bookseries/7854 (accessed on 15 November 2018).

40. Komatina, M.M. Medical Geology_Effects of Geological Environments on Human Health; Elsevier: New York, NY, USA, 2004.

41. Rasheed, T.; Bilal, M.; Nabeel, F.; Iqbal, H.M.; Li, C.; Zhou, Y. Fluorescent sensor based models for the detection of environmentally-related toxic heavy metals. Sci. Total Environ. 2018, 615, 476-485. [CrossRef] [PubMed] 
42. Bilal, M.; Rasheed, T.; Sosa-Hernández, J.; Raza, A.; Nabeel, F.; Iqbal, H. Biosorption: An interplay between marine algae and potentially toxic elements-A review. Mar. Drugs 2018, 16, 65. [CrossRef] [PubMed]

43. Hernandez-Vargas, G.; Sosa-Hernández, J.; Saldarriaga-Hernandez, S.; Villalba-Rodríguez, A.; Parra-Saldivar, R.; Iqbal, H. Electrochemical biosensors: A solution to pollution detection with reference to environmental contaminants. Biosensor 2018, 8, 29. [CrossRef]

44. Rasheed, T.; Li, C.; Bilal, M.; Yu, C.; Iqbal, H.M. Potentially toxic elements and environmentally-related pollutants recognition using colorimetric and ratiometric fluorescent probes. Sci. Total Environ. 2018, 640, 174-193. [CrossRef] [PubMed]

45. Rasheed, T.; Li, C.; Zhang, Y.; Nabeel, F.; Peng, J.; Qi, J.; Gong, L.; Yu, C. Rhodamine-based multianalyte colorimetric probe with potentialities as on-site assay kit and in biological systems. Sens. Actuators B Chem. 2018, 258, 115-124. [CrossRef]

46. Pérez, J.A.C.; Sosa-Hernández, J.E.; Hussain, S.M.; Bilal, M.; Parra-Saldivar, R.; Iqbal, H.M. Bioinspired Biomaterials and Enzyme-Based Biosensors for Point-of-Care Applications with Reference to Cancer and Bio-Imaging. Biocatal. Agric. Biotechnol. 2018. [CrossRef]

47. Rasheed, T.; Li, C.; Fu, L.; Nabeel, F.; Yu, C.; Gong, L.; Zhou, Y. Development and characterization of newly engineered chemosensor with intracellular monitoring potentialities and lowest detection of toxic elements. J. Mol. Liq. 2018, 272, 440-449. [CrossRef]

48. Koller, M.; Saleh, H.M. Introductory Chapter: Introducing Heavy Metals. In Heavy Metals; IntechOpen: Rijeka, Croatia, 2018.

49. Matos Alves, C.A.; Macedo, J.R.; Celestino Silva, L.; Serralheiro, A.; Peixoto Faria, A.F. Estudo geológico, petrológico e vulcanológico da ilha de Santiago (Cabo Verde). Garcia De Orta Serviços Geológicos 1979, 3, 47-74. (In Portuguese)

50. Instituto Nacional de Meteorologia e Geofisica (INMG). Climatologic Data of Some Stations in Santiago Island, Praia, Cabo Verde; Internal Report; INMG: Praia, Santiago Island, Cabo Verde, 2005.

51. United Nations Development Program for Cape Verde; PNUD: New York, NY, USA, 1993.

52. Martins, S.; Mata, J.; Munhá, J.; Madeira, J.; Moreira, M. Evidências geológicas e geoquímicas para a existência de duas unidades estratigráficas distintas na Formação do Pico da Antónia (Ilha de Santiago, República de Cabo Verde). Memórias E Notícias Universidade De Coimbra 2008, 3, 123-128. (In Portuguese)

53. Holm, P.; Grandvuinet, T.; Friis, J.; Wilson, J.R.; Barker, A.K.; Plesner, S. Na 40Ar-39Ar study of the Cape Verde hot spot: Temporal evolution in a semistationary plate environment. J. Geophys. Res. Solid Earth 2008, 113, B08201. [CrossRef]

54. Ramalho, R.; Helffrich, G.; Cosca, M.; Vance, D.; Hoffmann, D.; Schmidt, D.N. Vertical movements of ocean island volcanoes: Insights from a stationary plate. Mar. Geol. 2010, 275, 84-95. [CrossRef]

55. Ramalho, R.; Helffrich, G.; Schmidt, D.; Vance, D. Tracers of uplift and subsidence in the Cape Verde Archipelago. J. Geol. Soc. 2010, 167, 519-538. [CrossRef]

56. Tukey, J.W. Exploratory Data Analysis; Addison-Wesley: Reading, UK, 1977.

57. Minister of the Environment (Canada). Soil, Ground Water and Sediment Standards for Use under Part XV.1 of the Environmental Protection Act. Available online: http:/ / www.mah.gov.on.ca/AssetFactory.aspx?did= 8993 (accessed on 15 October 2018).

58. Ministry of Housing, Spatial Planning and the Environment (VROM). Circular on Target Values and Intervention Values for Soil Remediation. The Netherlands Government Gazette, No. 39, Ministry of Housing, Spatial Planning and Environment, Directorate General for Environmental Protection, Department of Soil Protection. Available online: http:/ / www.esdat.net/Environmental\%20Standards/Dutch/annexS_ I2000Dutch\%20Environmental\%20Standards.pdf (accessed on 16 October 2018).

59. USEPA (United States Environmental Protection Agency). Guidelines for Exposure Assessment, Risk Assessment Forum; [EPA/600/Z-92/001]; United States Environmental Protection Agency: Washington, DC, USA, 1992.

60. USEPA (United States Environmental Protection Agency). Exposure Factors Handbook 2011 Edition (Final); United States Environmental Protection Agency: Washington, DC, USA, 2011. Available online: http: / / cfpub.epa.gov/ncea/risk/recordisplay.cfm?deid=236252 (accessed on 18 September 2018).

61. USEPA (United States Environmental Protection Agency). Calculating Upper Confidence Limits for Exposure Point Concentrations at Hazardous Waste Sites; Publication 9285.6-10; Office of Emergency and Remedial Response: Washington, DC, USA, December 2002. 
62. USEPA (United States Environmental Protection Agency). Risk Assessment Guidance for Superfund: Volume III-Part A, Process for Conducting Probabilistic Risk Assessment; EPA 540-R-02-002; United States Environmental Protection Agency: Washington, DC, USA, 2001. Available online: https:/ /www.epa.gov/ sites/production/files/2015-09/documents/rags3adt_complete.pdf (accessed on 4 September 2018).

63. USDE (U.S. Department of Energy). The Risk Assessment Information System (RAIS); U.S. Department of Energy's Oak Ridge Operations Office: Oak Ridge, TN, USA, 2013. Available online: https:/ / rais.ornl.gov/ (accessed on 4 September 2018).

64. Cabral Pinto, M.M.S.; Ferreira da Silva, E.A.; Silva, M.M.V.G.; Melo-Gonçalves, P.; Candeias, C. Environmental risk assessment based on high-resolution spatial maps of potential toxic elements sampled on stream sediments of Santiago, Cape Verde. Geosciences 2014, 4, 297-315. [CrossRef]

65. Rudnick, R.L.; Gao, S. Composition of the Continental Crust. Treatise Geochem. 2003, 3, 659.

66. Chin-Chan, M.; Navarro-Yepes, J.; Quintanilla-Vega, B. Environmental pollutants as risk factors for neurodegenerative disorders: Alzheimer and Parkinson diseases. Front. Cell. Neurosci. 2015, 9, 124. [CrossRef] [PubMed]

67. IARC (International Agency for Research on Cancer). Chromium, Nickel and Welding. In Monographs on the Evaluation of Carcinogenic Risks to Humans; IARC: Lyon, France, 1990; Volume 49.

68. Sun, Y.; Zhou, Q.; Xie, X.; Liu, R. Spatial, sources and risk assessment of heavy metal contamination of urban soils in typical regions of Shenyang, China. J. Hazard. Mater. 2010, 174, 455-462. [CrossRef]

69. Xie, Y.; Chen, T.B.; Lei, M.; Yang, J.; Guo, Q.J.; Song, B. Spatial distribution of soil heavy metal pollution estimated by different interpolation methods: Accuracy and uncertainty analysis. Chemosphere 2011, 82, 468-476. [CrossRef] [PubMed]

70. Türkdoğan, M.K.; Kilicel, F.; Kara, K.; Tuncer, I.; Uygan, I. Heavy metals in soil, vegetables and fruits in the endemic upper gastrointestinal cancer region of Turkey. Environ. Toxicol. Pharmacol. 2003, 13, 175-179. [CrossRef]

71. Pellegriti, G.; De Vathaire, F.; Scollo, C.; Attard, M.; Giordano, C.; Arena, S.; Dardanoni, G.; Frasca, F.; Malandrino, P.; Vermiglio, F.; et al. Papillary thyroid cancer incidence in the volcanic area of Sicily. J. Natl. Cancer Inst. 2009, 101, 1575-1583. [CrossRef] [PubMed]

72. Duntas, L.H.; Doumas, C. The 'rings of fire'and thyroid cancer. Hormones 2009, 8, 249-253. [CrossRef] [PubMed]

73. Malandrino, P.; Scollo, C.; Marturano, I.; Russo, M.; Tavarelli, M.; Attard, M.; Richiusa, P.; Violi, M.A.; Dardanoni, G.; Vigneri, R.; et al. Descriptive epidemiology of human thyroid cancer: Experience from a regional registry and the "volcanic factor". Front. Endocrinol. 2013, 4, 65. [CrossRef] [PubMed]

74. Simonart, T. Role of environmental factors in the pathogenesis of classic and African-endemic Kaposi sarcoma. Cancer Lett. 2006, 244, 1-7. [CrossRef] [PubMed]

75. Hueper, W.C.; Payne, W.W. Experimental cancers in rats produced by chromium compounds and their significance to industry and public health. Am. Ind. Hyg. Assoc. J. 1959, 20, 274-280. [CrossRef] [PubMed]

76. Keane, W.M.; Atkins, J.P., Jr.; Wetmore, R.; Vidas, M. Epidemiology of head and neck cancer. Laryngoscope 1981, 91, 2037-2045. [CrossRef] [PubMed]

77. Hassanin, K.M.; El-Kawi, S.H.A.; Hashem, K.S. The prospective protective effect of selenium nanoparticles against chromium-induced oxidative and cellular damage in rat thyroid. Int. J. Nanomed. 2013, 8, 1713.

78. Khlifi, R.; Olmedo, P.; Gil, F.; Hammami, B.; Chakroun, A.; Rebai, A.; Hamza-Chaffai, A. Arsenic, cadmium, chromium and nickel in cancerous and healthy tissues from patients with head and neck cancer. Sci. Total Environ. 2013, 452, 58-67. [CrossRef]

79. Kasim Baltaci, A.; Belviranli, M. Serum levels of calcium, selenium, magnesium, phosphorus, chromium, copper and iron-Their relation to zinc in rats with induced hypothyroidism. Acta Clin. Croat. 2013, 52, 151-156.

(C) 2018 by the authors. Licensee MDPI, Basel, Switzerland. This article is an open access article distributed under the terms and conditions of the Creative Commons Attribution (CC BY) license (http:/ / creativecommons.org/licenses/by/4.0/). 